\title{
$\mathrm{X}$ 線法によるポリイミド基板スパッ夕銅薄膜の変形挙動の評価*
}

\author{
秋庭義 明*1，木村 英 彦*1，鈴 木 剛 ${ }^{* 2}$
}

\section{Evaluation of Deformation Behaviour of Cu Thin Films Sputtered on Polyimide Films by X-Ray Method}

\author{
Yoshiaki AKINIWA*3, Hidehiko KIMURA and Tsuyoshi SUZUKI \\ ${ }^{* 3}$ Department of Mechanical Science \& Engineering, Nagoya University, \\ Furo-cho, Chikusa-ku, Nagoya-shi, Aichi, 464-8603 Japan
}

\begin{abstract}
Copper thin films were fabricated by $\mathrm{RF}$-magnetron sputtering under target power densities of 0.5 and $5 \mathrm{~W} / \mathrm{cm}^{2}$. The polyimide film was used as a substrate to apply a plastic deformation to the copper thin film. Average grain sizes of the copper films obtained at $5 \mathrm{~W} / \mathrm{cm}^{2}$ were $125 \mathrm{~nm}$ and 230 $\mathrm{nm}$. On the other hand, the sizes at $0.5 \mathrm{~W} / \mathrm{cm}^{2}$ were about $50 \mathrm{~nm}$. Load-controlled and strain controlled cyclic deformation tests were conducted on the polyimide films where the copper films deposited. Stress, full width at half maximum (FWHM) of diffraction profile, crystallite size, and microstrain of the copper films were measured during the deformation tests using X-ray method. In the load-controlled tests, the crystallite size decreased with applied strain during loading period, although the applied strain hardly affect crystallite size during unloading. On the other hand, the microstrain during unloading period was sensitive to the applied strain : the microstrain increased after initial rapid decrease. In the strain-controlled tests, the $\mathrm{X}$-ray stress averaged over a strain cycle decreased with strain cycles. This is because the copper film was subjected to large plastic deformation which can cause internal compressive stress during unloading. The averaged value of the FWHM decreased also with strain cycles. This decrease in the FWHM was consistent with texture development during cyclic loading. On the other hand, the changes in the crystallite size and the microstrain during cyclic loading were insignificant.
\end{abstract}

Key Words : X-Ray, Copper Thin Film, Plastic Deformation, Fatigue, Line Broadening, Crystallite Size, Microstrain

\section{1. 緒言}

MEMS や電子デバイス産業では薄膜技術が極めて 重要な役割を果たしており, 薄膜を機能構造材料とし て用いた製品の開発が進められている。.また，摩擦摺 動特性の向上や，防湿，防錆を目的とした要素部材も 多く, 広範な産業分野で薄膜技術の応用が進められて いる.

これら薄膜製品の実用にあたっては, 変形・強度の 観点からの信頼性の確保が要求されるが, 薄膜化によ つて絨維配向の現出や結晶粒径の微細化が生じること から, 従来のバルク材とは異なる变形・強度特性を有 する可能性があり ${ }^{(1) \sim(4)}$ ，強度特性を定量的に評価し， 破壊機構を明確にすることが求められる。

* 原稿受付 2008 年 6 月 4 日.

*1 正員, 名古屋大学大学院工学研究科( 464-8603 名古屋市 千種区不老町)

*2 正員, 名古屋大学大学院工学研究科.

E-mail : akiniwa@mech.nagoya-u.ac.jp
Read ら(5)は，半導体デバイス製造技術を用いて微小 な銅薄膜単体試料を作成して機械特性を評価している. しかしながら試料作成が煩雑なことや，通常何らかの 基板上に密着した状態で薄膜が用いられることから， シリコンやガラス等のぜい性材料や(3)(6)，鉄鋼材料を 基板として ${ }^{(8)}$ ，成膜された状態で緉維配向，熱サイク ルおよび負荷状態での薄膜の变形特性評価がなされて いる. また, ナノインデンデション法による局所領 域の変形挙動の評価も試みられているが9(10), 膜全体 として，比較的大きなひず夕領域までの変形特性の評 価は困難であった。 これに対して, Schadler ら 高分子材料を基材として，その上に銅薄膜を成膜して 変形挙動を評価した. Hommel ら て, 単軸負荷過程での変形挙動を高ひずみ範囲まで詳 細に観察している. また Kraft らは疲労強度特性の評価 に応用している ${ }^{(13)(14)}$ ．しかしながら，静的な負荷に対 しては, 主に負荷過程に注目して単調負荷下での変形 挙動について検討されており,また，およそ $300 \mathrm{~nm}$ 以 
上の結晶粒径の材料が対象で，それ以下の粒径の薄膜 については明らかでない.

そこで本研究では， スパッ夕条件を変化させるこ とによって, 結晶粒径を $50 \mathrm{~mm}$ から $230 \mathrm{~nm}$ とした銅薄 膜をカプトンフィルム上に成膜し，除荷過程を含む単 軸負荷および片振りの疲労試験を実施するとともに, $\mathrm{X}$ 線法を用いて変形過程での薄膜の応力を直接測定す るとともに，結晶子寸法および微視ひずみ变化の観点 から変形挙動を検討した.

\section{2. 実験方法}

$2 \cdot 1$ 材料及ひ試験片 銅薄膜の成膜は RF ミニ スパッ夕装置(ULVAC, MNS-2000-RF-T)を用いて行つ た. ターゲットにはフルウチ化学社製の $99.99 \% \mathrm{Cu}$ を 用いた. 基板には東レ・デュポン社製のポリイミドフィ ルム(カプトン 500H)を用いた. ポリイミドフィルムの 厚さは $125 \mu \mathrm{m}$ である. まずフィルムを幅 $6 \mathrm{~mm}$ の短冊 状に切取り，アセトンにて超音波洗浄を行った後，加 エひずみを除去するために $300^{\circ} \mathrm{C}, 1 \mathrm{~h}$ の真空焼なまし を施したものを用意した. 成膜領域長が $30 \mathrm{~mm}$ 以上に なるようにテフロンテープを用いてスパッタ装置試料 台に取付けた. ターゲットと基板の間隔は $70 \mathrm{~mm}$ であ る. 成膜条件を表 1 に示す，以下では，ターゲット出 力密度 $5 \mathrm{~W} / \mathrm{cm}^{2}$ で成膜した 2 材を $\mathrm{T} 1, \mathrm{~T} 2,0.5 \mathrm{~W} / \mathrm{cm}^{2}$ で成膜した 2 材を $\mathrm{T} 3, \mathrm{~T} 4$ と称する.

$2 \cdot 2$ 薄膜の表面性状観察 膜厚の測定はレーザ 顕微鏡(KEYENCE 社製：VK-9510)，および光干涉方式 非接触顕微鏡(ZYGO New View 6200)を用いて行った. レーザ顕微鏡による測定は対物レンズ 50 倍, ピッチ $0.01 \mu \mathrm{m}$ にて行い, 光干渉方式非接触顕微鏡による測定 は対物レンズ 10 倍にて行った. 測定は両装置とも, テ フロンテープにてマスキングされて成膜されていない 部分と，成膜された部分の段差を測定することにより 行った. 1 つの試験片につき，両端近傍と中央部近傍 の 3 箇所の画像を得た後, 1 つの画像につき 3 点, 合

Table 1 Conditions for deposition of copper film.

\begin{tabular}{|c|c|c|c|c|c|}
\hline \multicolumn{2}{|c|}{ Specimen No. } & T1 & $\mathrm{T} 2$ & T3 & $\mathrm{T} 4$ \\
\hline \multirow{2}{*}{$\begin{array}{l}\text { Loading } \\
\text { type }\end{array}$} & Static & 0 & - & 0 & - \\
\hline & Fatigue & - & 0 & - & $\mathrm{O}$ \\
\hline \multicolumn{2}{|c|}{ Base pressure, $\times 10^{-5} \mathrm{~Pa}$} & \multicolumn{4}{|c|}{3.7} \\
\hline \multicolumn{2}{|c|}{ Working gas } & \multicolumn{4}{|c|}{$\mathrm{Ar}$} \\
\hline \multicolumn{2}{|c|}{ Working gas pressure, $\times 10^{-1} \mathrm{~Pa}$} & \multicolumn{4}{|c|}{5} \\
\hline \multicolumn{2}{|c|}{ Gas flow rate, sccm } & 13.5 & 15 & 14.5 & 14.5 \\
\hline \multicolumn{2}{|c|}{ Target power density, $P$ W/cm ${ }^{2}$} & \multicolumn{2}{|c|}{5} & \multicolumn{2}{|c|}{0.5} \\
\hline \multicolumn{2}{|c|}{ Deposition time, $\min$} & \multicolumn{2}{|c|}{37.5} & \multicolumn{2}{|c|}{628} \\
\hline \multicolumn{2}{|c|}{ Film thickness, $h \mu \mathrm{m}$} & 1.77 & 1.78 & 1.89 & 1.89 \\
\hline \multicolumn{2}{|c|}{ Grain size, $d \mathrm{~nm}$} & 229 & 125 & 50.8 & 54.3 \\
\hline
\end{tabular}

計 9 点の段差を測定し，その平均を膜厚とした．成膜 時には膜厚が $2 \mu \mathrm{m}$ 程度になるように成膜時間を調整 した. 最終的な膜厚は表 1 に示すように 1.8 から $1.9 \mu \mathrm{m}$ である. 各基板上の $\mathrm{Cu}$ 薄膜の結晶粒径は，電界放射 型電子顕微鏡 FE-SEM（JEOL JSM-7000F）を用いて表 面観察を行つた. 図 1(a)にT2 試験片の SEM 写真を示 す．ほぼ等軸粒状の個々の粒が明瞭に判別できる．図 (b)は同一試料について電子線後方散乱像法によって 得られた(ただし観察位置は異なる)逆極点図(IPF マッ プである. IPF マップで観察される個々の結晶粒の大 きさは SEM 像で観察される粒の大きさにほぼ対応し ており，粒の一つが一結晶に対応することがわかる.

線分法で得られる結晶粒径は $125 \mathrm{~nm}$ である. 他の試料 の写真は省略するが T1 の粒径は $229 \mathrm{~nm}$ で, $0.5 \mathrm{~W} / \mathrm{cm}^{2}$ では $51 \mathrm{~nm}$ および $54 \mathrm{~nm}$ となり, ターゲット出力密度 が小さい方が結晶粒径は小さくなった。

$2 \cdot 3$ 負荷過程での X 線測定 結晶の配向および 薄膜の応力は, X線回折装置 (Mac Science 社製:M21X) を用いて測定した．表面法線方向に関する配向性の確 認は 111，200 および 220 回折の強度を比較した. 薄膜 中の応力は, X線回折装置にステッピングモー夕を利 用した引張負荷装置を取り付けて基板ごと負荷してそ の場測定を行った (15)(16). 所定の荷重までマニュアルで 負荷し，変位を固定した状態で $\mathrm{X}$ 線測定を行った. 特 性 X 線には Cr-K $\alpha$ 線を用い, Cu 220 回折を用いた. X 線条件を表 2 に示す. なお, X 線的弾性定数は結晶粒 径が $10 \mu \mathrm{m}$ の電解銅簿で得られた值である -504MPa/deg を用いた ${ }^{(15)}$. 公称ひずみは, 高精度レー ザ変位計（KEYENCE 社製：LC-2400）によって測定 された変位より算出した. ゲージ長さ(チャック間距

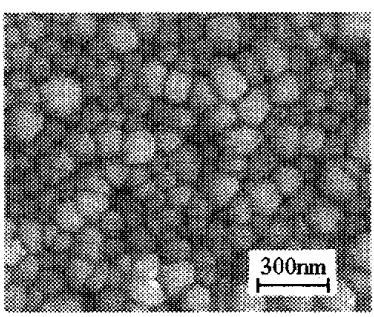

(a) SEM image.

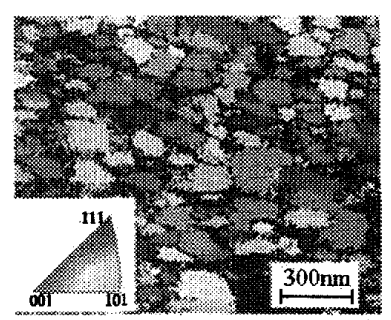

(b) IPF map.
Fig. 1 Grain observation (T2 specimen).

Table 2 Conditions for X-ray stress measurement

\begin{tabular}{c|c}
\hline Characteristic X-ray & $\mathrm{Cr}-\mathrm{K} \alpha$ \\
\hline Diffraction plane & $\mathrm{Cu} 220$ \\
\hline Diffraction angle, $2 \theta$ deg & 127.22 \\
\hline Tube voltage, $\mathrm{kV}$ & 40 \\
\hline Tube current, $\mathrm{mA}$ & 200 \\
\hline Tilt angle, $\sin ^{2} \psi$ & $0 \sim 0.5$ \\
\hline
\end{tabular}




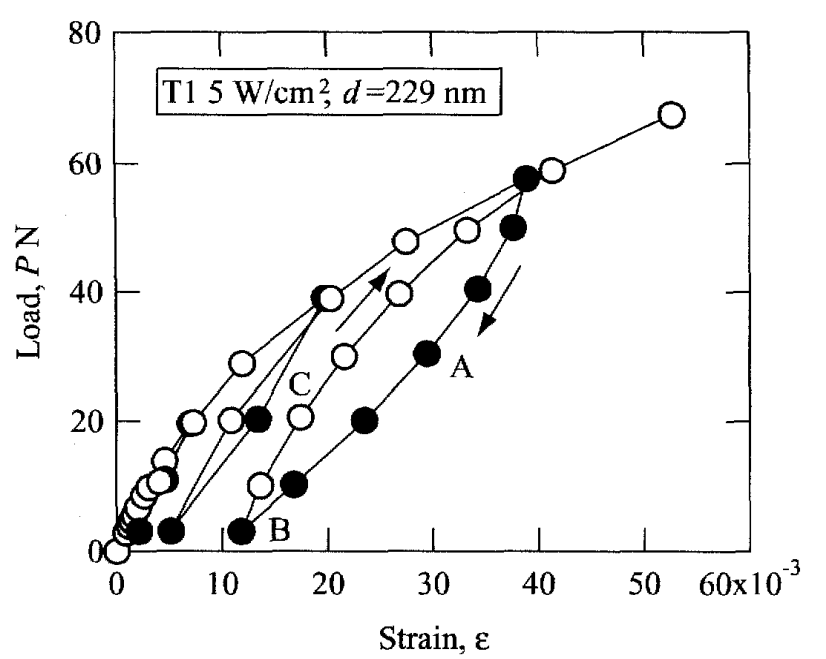

(a) Relation between applied load and strain

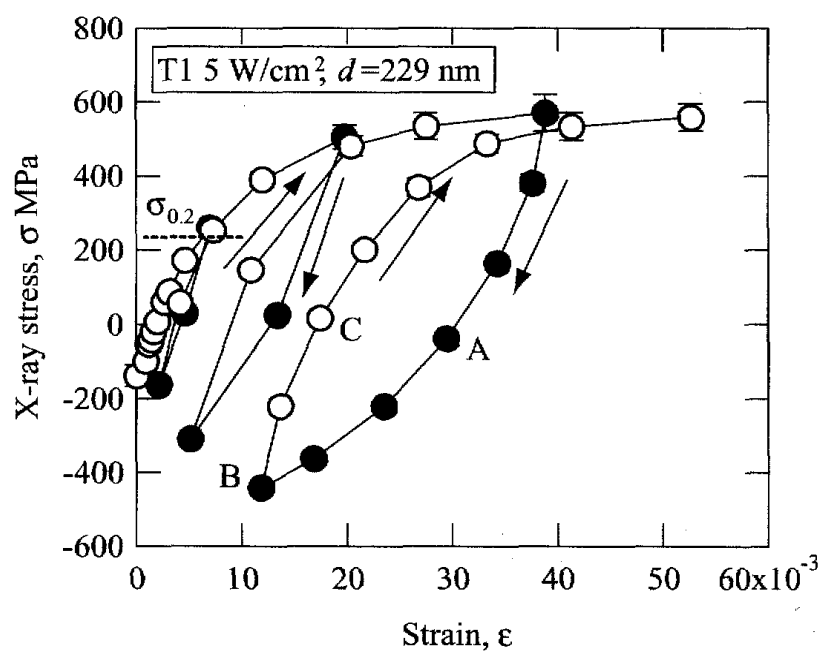

(b) Relation between X-ray stress and strain

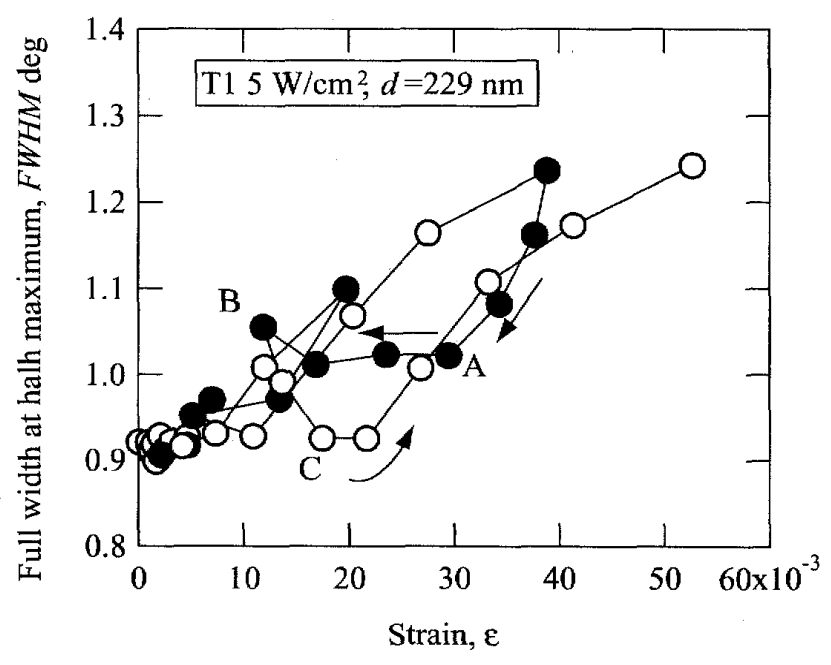

(c) Relation between FWHM and strain

Fig.2 Change of X-ray parameters during loading ( $\mathrm{T} 1$ specimen, $5 \mathrm{~W} / \mathrm{cm}^{2}$ ).

離)は $20 \mathrm{~mm}$ で, 変位測定分解能は $0.2 \mu \mathrm{m}$ である. な お, $\mathrm{Cr}-\mathrm{K} \alpha$ 線によるX線有効侵入深さは約 $3 \mu \mathrm{m}$ であり,
試験片の厚み全体にわたる重み付き平均が得られてい る.また, 回折線幅はばらつきを考慮して, $\sin ^{2} \psi=0$, 0.1 にて得られた值の平均を採用した.

$2 \cdot 4$ 疲労試験 疲労負荷時の変形挙動を観察 するために疲労試験を行った. 最低荷重を $3 \mathrm{~N}$, ひず み幅を $\Delta \varepsilon=1 \%$ として, サイクル数 1～30 回までは上述 の引張負荷装置を用いてマニュアルで負荷した. それ 以降は電磁力式微小試験機(島津製作所, MMT250NB-10 : ロードセル容量 $250 \mathrm{~N}$ )を用いて周波数 0.1 $\mathrm{Hz}$ にて行った. 試験条件の設定は，手動負荷時に測定 された最大荷重を参考に荷重制御とした. 疲労試験中 にはラチェット変形が進行するが，試験中はひずみ幅 を常時モニターし， $\Delta \varepsilon=1 \%$ となるように随時荷重を調 整した. 所定の繰返し数に達した時点で, 試料を疲労 試験機から弓張負荷装置に付け替えてX線応力測定を 行った. 繰返し数は 1000 回までとした.

\section{3. 実験結果及ひ考察}

\section{$3 \cdot 1$ 除荷を伴う静的負荷下における变形挙動} 得られた銅薄膜の配向性は，ほぼ既報 ${ }^{(15)}$ で報告した電 解銅薄膜と同様で, JCPDS4-836 による回折強度と比較 すると Cu 220 回折の相対強度が高く, Cu 111 を基準 とした場合, JCPDS カードの Cu 220 回折強度 0.2 に対 して 0.8 か 1.4 である.

試料 $\mathrm{T} 1$ および $\mathrm{T} 3$ を用いて単軸負荷下の変形挙動を 検討した. 図 2(a)にターゲット出力密度 $5 \mathrm{~W} / \mathrm{cm}^{2}$ のT1 試験片で得られた負荷荷重とひずみの関係を示す. 図 中の黒印は除荷過程のデータを示している. 図のよう に, 負荷荷重が 20,40 および $60 \mathrm{~N}$ に達した時点で, 3 $\mathrm{N}$ まで除荷し, その後再び負荷している. 図中に示し た A および C は, 後述のようにX 線応力がほぼゼロ になったときのデー夕点を示している.

この試料のX 線的灾力とひずみの関係を図 2(b)に示 す. 通常の機械的な $0.2 \%$ 耐力を求める場合と全く同じ 手順で， $\mathrm{X}$ 線的応力に関して求められた $0.2 \%$ 耐力は $223 \mathrm{MPa}$ であり, 図中に破線で示した。最初の除荷サ イクルはほぼ弾性的な変化を示しており, ル一プは小 さいが, $40 \mathrm{~N}$ から除荷した 2 番目のサイクルでは, 最 低荷重点での応力は初期值の残留応力値よりも小さく なる.これは銅薄膜よりもカプトンフィルムの塑性変

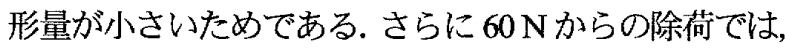
その傾向が顕著であり，ループも大きくなる.

半価幅とひずみの関係を図 2(c)に示す. 全ひずみで $0.7 \%$ 程度以上で半価幅の值が急増する. 第 3 回目の除 荷過程に注目する. 最大負荷荷重である $60 \mathrm{~N}$ から除荷 すると, 大きな塑性変形によって増加した半価幅は, 


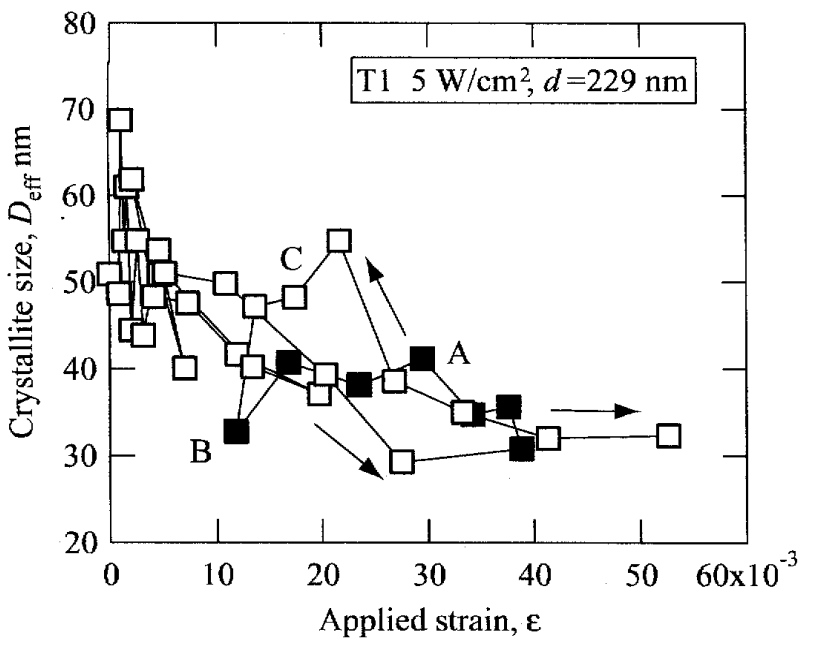

(a) Change of crystallite size

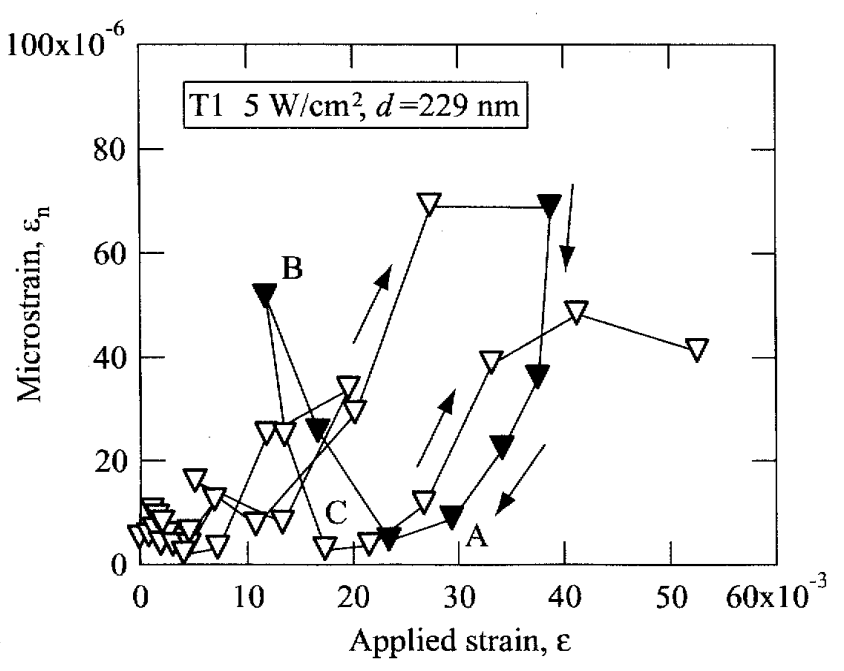

(b) Change of microstrain

Fig.3 Results of profile analysis for static loading (T1 specimen, $5 \mathrm{~W} / \mathrm{cm}^{2}$ ).

$\mathrm{X}$ 線的応力がほぼゼ口となる $\mathrm{A}$ 点までは, 除荷ととも に低下し，その後一定となる. 負荷荷重が $3 \mathrm{~N}$ となる $\mathrm{B}$ 点の直前までは一定のままで, $\mathrm{B}$ 点になると再び増 加する.この増加は, $\mathrm{X}$ 線応力が圧縮側に大きくなつ たことからわかるように，压縮の塑性変形によっても たらされたものと考えられる. その後, 再負荷過程で は半価幅が低下して，C 点で最小值となり，このとき の值はほぼ初期值に等しくなる点は興味深い。さらに 負荷荷重を増加させると，半価幅は再び増加する.

Warren 法 ${ }^{(17)}$ によるプロファイル解析によって得ら れた結晶子寸法と負荷ひずみの関係を図 3(a)に示す. 基準材料には銅の粉末材を用いた．図中の黒塗り印は やはり除荷過程でのデータを示しているが，煩雑さを 避けるために, 負荷荷重が $60 \mathrm{~N}$ からの場合のみを黒塗 りで示した. 全体的にばらつきが大きいが，おおよそ 初期值の $50 \mathrm{~nm}$ 程度から, 負荷とともにやや減少し,
最大の負荷ひずみでおおよそ $32 \mathrm{~nm}$ 程度となる.これ は負荷過程に発生増殖した転位が結晶子として検出さ れるような転位ネットワーク構造を形成したことが原 因と考えられる. $60 \mathrm{~N}$ からの除荷過程についてみると, 除荷過程では若干増加する傾向が認められるが，その 程度は小さい，最低負荷荷重の B 点では再び小さくな る傾向が認められる. 一方, 再負荷過程では再度増加 しており，C点付近では初期值にほぼ等しくなる.

図 3(b)は微視ひずみ ${ }^{(17)}$ の変化を示した. 全ひずみが おおよそ $0.7 \%$ 程度より大きくなると, 負荷とともに微 視ひずみが急激に増加する.この挙動は図 2(c)の半価 幅の増加傾向とよく対応している. 除荷過程では除荷 とともに微視ひずみは急激に減少し, A 点近傍で最小 值をとり，このときの值はほぼ初期值に等しい. 負荷 荷重が最小となる $\mathrm{B}$ 点では，微視ひずみが再び増加し ており, やはり半価幅変化に対応していることがわか る.このことからも, B 点では圧縮の塑性変形が生じ たことが伺える. 再負荷過程では，微視ひずみが再び 減少し，C 点でほぼ初期值となる. 以上より, 半価幅 変化の主要因は微視ひずみの変化であることがわかる.

なお結果は省略するが, 結晶粒径が $51 \mathrm{~nm} の \mathrm{~T} 3$ 材 においては, 除荷過程で $X$ 線応力がゼロになった時点 で半価幅が初期値に戻ることを除いて，変化傾向はほ ぼ同様であった。

以上のことから，図 2(c)における初期の負荷過程に おける半価幅の増加は, 転位の増殖による微視ひずみ の増加とともに，結晶子として検出されるような転位 ネットワーク構造の形成に対応しており，除荷過程に おいては, 発生した可動転位か除荷の初期に粒界等に 吸収されて消滅するものの, ネットワーク構造が完全 には解消されないことが示唆される. 再負荷過程にお いて圧縮時に増殖した転位が消滅するとともに，ネッ トワーク構造も解消されて初期に近い状態までもどる ものと推察することができる. ただし再負荷過程で初 期状態にまで戻る機構については今後検討の必要があ ろう。また，微小結晶粒材の変形過程においては，せ ん断帯が形成されることが報告されているが(18)，本研 究では負荷後に発生したき裂近傍でも, 'せん断帯やす ベり帯は観察されなかった。これは，ポリイミド基盤 の一様変形のために，銅薄膜単体の変形挙動とは異な る形態が観察された可能性も考えられ，今後検討が必 要である.

なお本研究では，平行ビーム法による Cu220 回折プ ロファイルに対して解析を行っているため, 必ずしも 厳密なものではないが，おおよその傾向は捉えられて いるものと考えられる. 


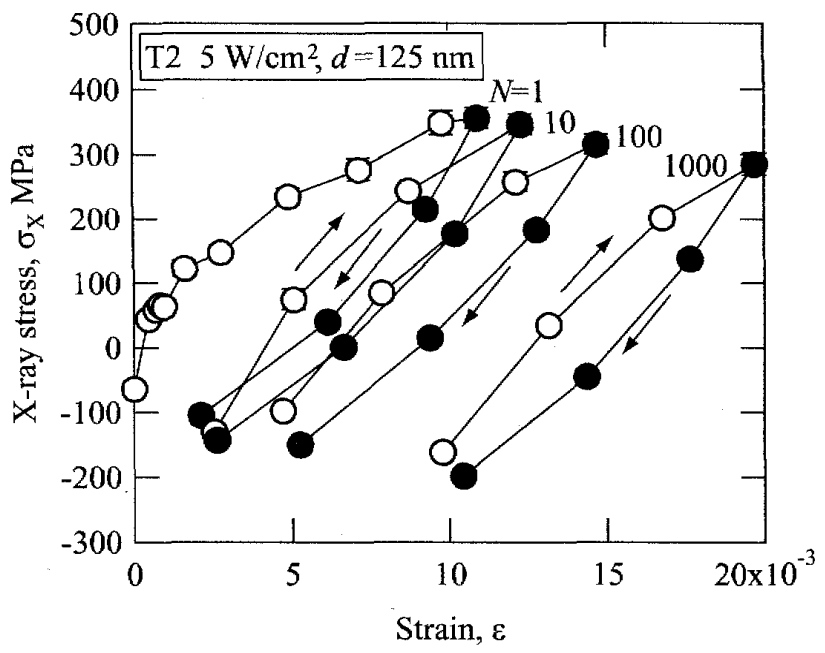

(a) Relation between X-ray stress and strain

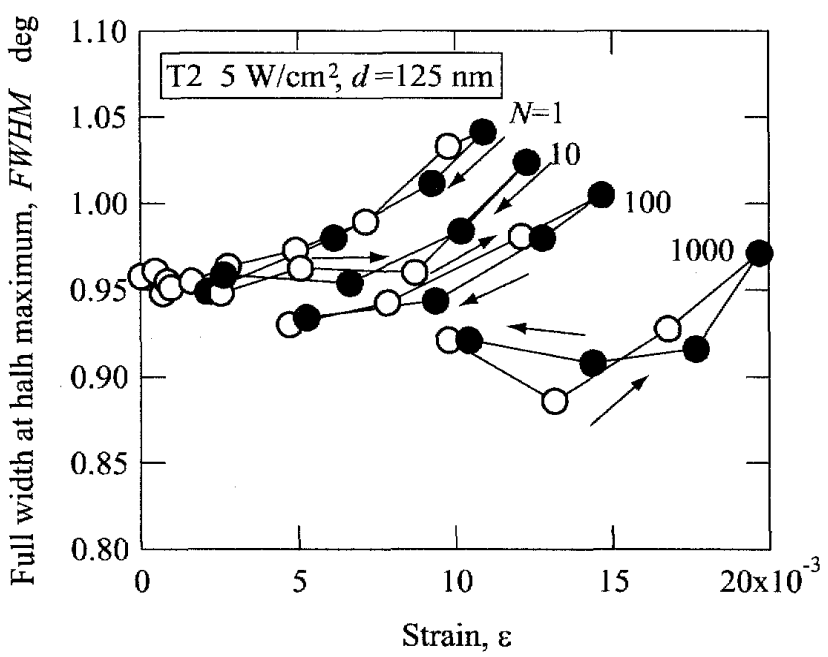

(b) Relation between FWHM and strain

Fig.4 Change of $\mathrm{X}$-ray parameters during fatigue (T2 specimen, $5 \mathrm{~W} / \mathrm{cm}^{2}$ )

以上の議論は限られたX線測定デー夕に基づくもの であり，具体的な転位構造に関しては明らかでない。 転位構造については, TEMによる直接的観察が最も有 効であるが，本結果からわかるように，除荷状態のみ ならず負荷過程での観察が必要であり, TEM 内その場 観察が望まれる.

$3 \cdot 2$ 疲労過程における变形挙動 構造用材料と して薄膜を利用するためには絽返し疲労に対する変形 挙動の把握も重要である. 図4(a)は結晶粒径が $125 \mathrm{~nm}$ の $\mathrm{T} 2$ 材の疲労試験中の $\mathrm{X}$ 線的応力の変化を示したも のである. 全ひずみ範囲が $1 \%$ も, 試料全体としての ラチェット変形が進行し，全ひずみが増加することが わかる. 銅薄膜の塑性ひずみはポリイミド基板のそれ よりも大きいために, 絽返しとともにX 線応力は全体 として減少するものの, 全応力範囲はほぼ $500 \mathrm{MPa}$ 程

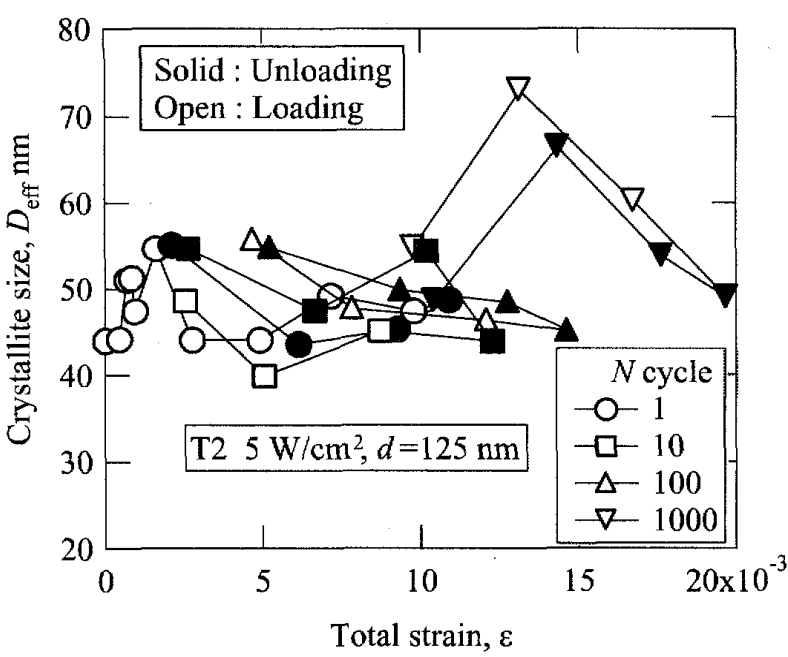

(a) Change of crystallite size

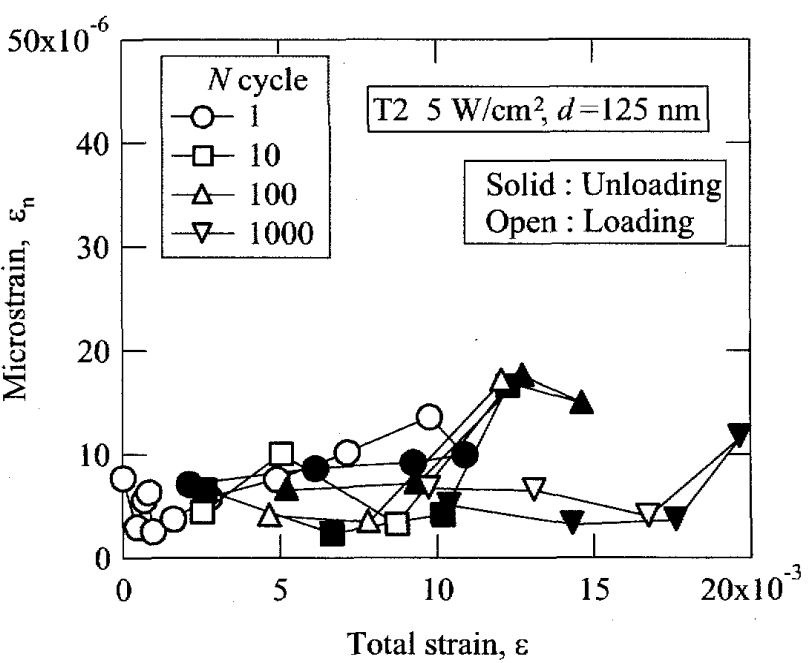

(b) Change of microstrain

Fig. 5 Results of profile analysis for fatigue loading ( $\mathrm{T} 2$ specimen, $5 \mathrm{~W} / \mathrm{cm}^{2}$ )

度で一定であり，ループ幅もほぼ一定である. 図 4(b) はこのときの半価幅変化である. 個々のループについ てはいずれも右上がりであり，負荷ひずみの増加とと もに半価幅は増加する. 一方, 絽返しに伴う変化に注 目すると, 静的負荷の場合とは傾向が異なり，全ひず みが増加しているにもかかわらず半価幅は減少してお り, $N=1000$ 回では初期值よりも小さな值をとることが わかる. なお，結晶粒径が $54 \mathrm{~nm}$ の $\mathrm{T} 4$ 材でも挙動は ほぼ同様であった。

図 5 はこのときの結晶子寸法と微視ひずみの変化を 示したものである. 繰返しに伴う系統的な傾向は明膫 ではない. Zhang ら ${ }^{(14)}$ は粒径が $300 \mathrm{~nm}$ 程度以上の銅薄 膜に対して全ひずみ範囲 $1 \%$ 程度の疲労試験を実施し, 粒径が $300 \mathrm{~nm}$ より小さくなると, $5 \times 10^{3}$ 回の繰返し後 でもセル構造が生じなくなることを報告しており，本 


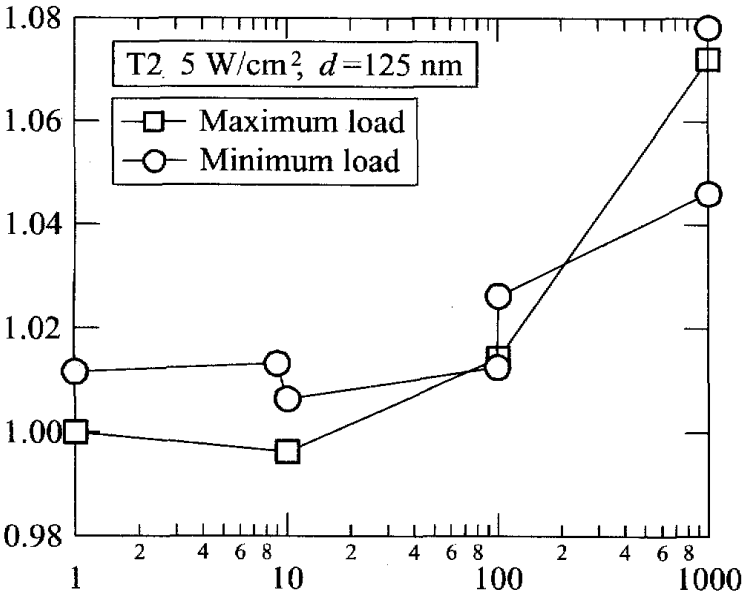

Number of cycles, $N$ cycle

(a) Fatigue loading $\left(\mathrm{T} 2,5 \mathrm{~W} / \mathrm{cm}^{2}\right)$

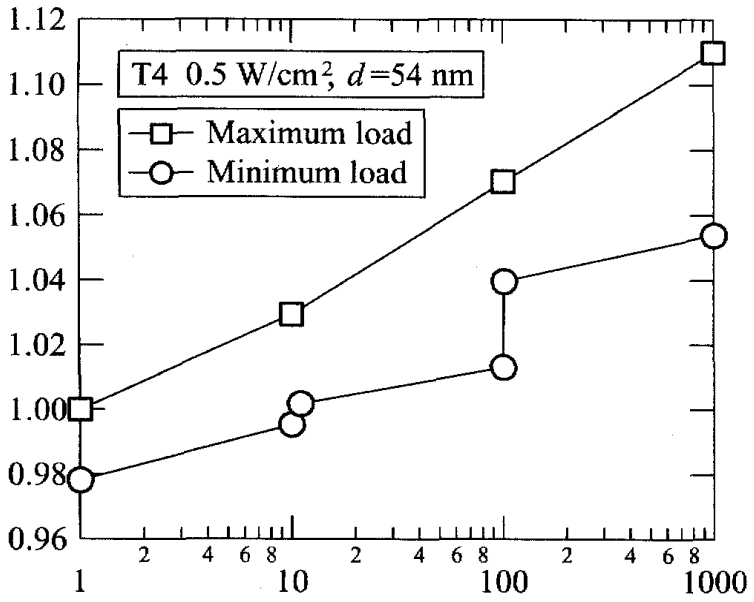

Number of cycles, $N$ cycle

(b) Fatigue loading (T4, $0.5 \mathrm{~W} / \mathrm{cm}^{2}$ )

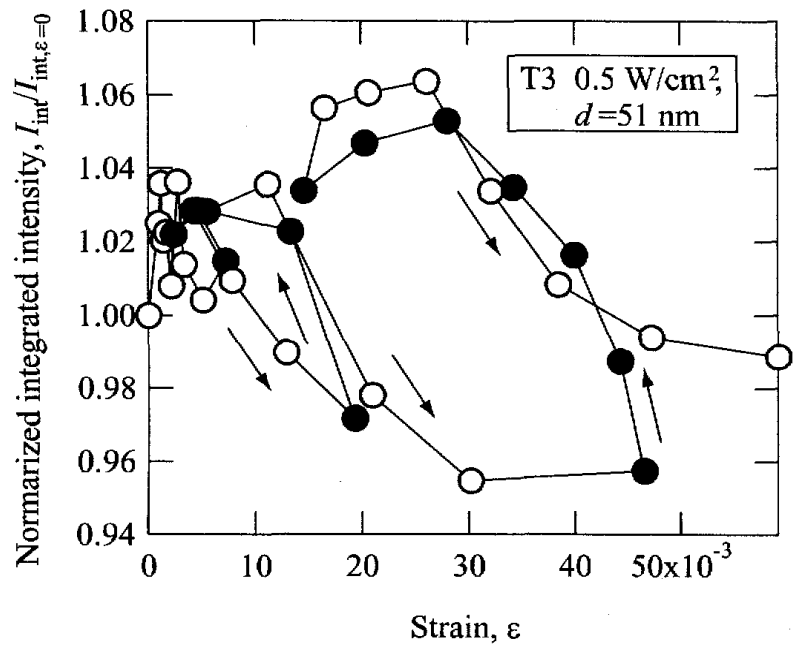

(c) Static loading $\left(\mathrm{T} 3,0.5 \mathrm{~W} / \mathrm{cm}^{2}\right)$

Fig. 6. Change of diffraction intensity during loading
Table 3 Normalized diffraction intensity

\begin{tabular}{|c|c|c|c|c|}
\hline & \multicolumn{2}{|c|}{$\mathrm{T} 2(100 \mathrm{~W})$} & \multicolumn{2}{|c|}{$\mathrm{T} 4(10 \mathrm{~W})$} \\
\hline & $I_{\text {Int }, 200}$ & $I_{\text {Int, } 220}$ & $I_{\text {Int,200 }}$ & $I_{\text {[nt }, 220}$ \\
\hline (cyc & $\overline{I_{\mathrm{In}, 111}}$ & $\frac{\mathrm{m}, 220}{I_{\mathrm{Int}, 111}}$ & $\frac{1,200}{I_{\text {[nt, }, 111}}$ & $\frac{m_{1,220}}{I_{[\mathrm{nn}, 111}}$ \\
\hline$\overline{0}$ & 0.536 & 0.819 & 0.760 & 1.38 \\
\hline 1000 & 0.549 & 1.055 & 0.820 & 1.90 \\
\hline Ratio & 1.02 & 1.29 & 1.08 & 1.38 \\
\hline
\end{tabular}

実験結果とよく対応している.T4 材でも傾向は同じで あった. 絽返しに伴う半価幅の隇少挙動はこれらのパ ラメータ変化からは説明できない．また，巨大ひずみ 加工付与によるナノ結晶材料においては, 疲労過程で の動的回復や結晶の粗大化が指摘されているが(19)(20), 本材料のX線法による観察ではその傾向は顕著でない ことがわかる.

図6(a)および(b)は，T2 およびT4 の最大鱼荷時およ び最小負荷時における 220 回折の積分強度の絽返しに 伴う変化を示した. 積分強度は $N=1$ における最大荷重 負荷時の值で正規化している．繰返しとともに 220 回 折の強度は増加しており，負荷過程において配向特性 が変化していることがわかる. 表 3 には 111 回折強度 で正規化した 200 および 220 回折強度を示す．いずれ の材料も繰返しによって 200 および 220 回折ともに疲 労負荷によって相対強度が増加していることがわかる. すなわち, 繰返しに伴う 220 回折の半価幅の減少は, 加工による集合組織の発達のように，負荷過程におい て個々の結晶が特定の結晶方位に優先的に配向するこ とによって散乱べクトルの力向のばらつきが小さくな ったことが示唆される. ただし，本結果からは，塑性 変形に対して粒内すべりおよび粒界すべりのいずれが 優先的かは明らかでない，一方，T3材による静的負荷 の結果を図 6(c)に示す．縦軸は負荷前の值で正規化し ている. 図よりわかるように，負荷過程では回折強度 が減少し，除荷によって増加する傾向が認められる. このような除荷過程の変形挙動が，疲労負荷において も重要な役割を果たすものと考えられるが，詳細につ いては今後さらに検討の必要がある.

以上のように, 本研究では X 線回折法を用いること によって，負荷およひ除荷過程での変形挙動に関する データが容易に得られることを示した．ただし，転位 構造の詳細な確認には，前述のように TEM によるそ の場観祭が不可欠であり，また配向性の変化について は EBSD 法等の結晶方位解析が有用なツールと考えら れる. 今後これらを通して, X 線パラメー夕変化の物 理的な意味を明らかにするとともに, 高強度な薄膜材 料の開発につながる因子を抽出することが必要である. 


\section{4. 結言}

カプトン基板にスパッタリングによって成膜した $\mathrm{Cu}$ 薄膜について静的引張試験および疲学試験を行い, 変形挙動を X 線法によって観察した. 得られた結果を まとめると以下のようになる.

（1）静的負荷においては, 塑性変形の進行とともに半 価幅が増加するものの, 除荷によって初期值に近い值 まで減少した。これは, 結晶子寸法の変化および微視 ひずみの変化に対応し，特に微視ひずみの変化に強く 依存した。

（2）疲労過程においては，ラチェット変形のためにX 線的応力は繰返しとともに全体的に低下するものの, 変化量およびループ幅はほぼ一定である. また，半価 幅は繰返しとともに減少した。一方, 結晶子寸法およ び微視ひずみの変化は顕著でない。

（3） 111 回折に対する 200 および 220 回折の相対強度 は繰返しとともに増加した.これは, 繰返し変形によ る優先配向の形成を示陵しており，繰返しによる 220 回折の半価幅の減少に対忘している.

（4）静的負荷およひ疲労負荷下における変形挙動は, 平均結晶粒径が約 $50 \mathrm{~nm} \sim 230 \mathrm{~nm}$ では大きな違いは認 められなかった。

\section{文献}

(1) Hommel M. and Kraft O., Deformation behavior of thin copper films on deformable substrates, Acta Materialia, Vol. 49 (2001), pp. 3935-3947.

(2) Klein M., Hadrboletz A., Weiss B. and Khatibi G., The 'size effect' on the stress-strain, fatigue and fracture properties of thin metallic foils, Materials Science and Engineering, Vol. A319-321 (2001), pp. 924-928.

(3) Baker S.P., Kretschmann A. and Arzt E., Thermomechanical behavior of different texture components in $\mathrm{Cu}$ thin films, Acta Materialia, Vol. 49 (2001), pp. 2145-2160

(4) Sonnweber-Ribic P., Gruber P., Dehm G. and Arzt E., Texture transition in $\mathrm{Cu}$ thin films: Electron backscatter diffraction vs. X-ray diffraction, Acta Materialia, Vol. 54 (2006), pp. 3863-3870 .

(5) Read D.T. and Dally J.W., A new method for measuring the strength and ductility of thin films, Journal of Materials Research, Vol. 8 (1993), pp. $1542-1549$.

(6) Hanabusa T., Kusaka K. and Sakata O., Residual stress and thermal stress observation in thin copper films, Thin Solid Films, Vol. 459 (2004), pp. 245-248.

(7) Tanaka K., Ito T., Akiniwa Y. and Ohta H., In-situ synchrotron measurement of thermal stress in textured copper thin films during thermal cycling, Journal of the Society of Materials Science, Japan, Vol. 53 (2004), pp. 728-73.

(8) Qina M., Jib V., Wuc Y.N., Chena C.R. and Li J.B., Determination of proof stress and strain-hardening exponent for thin film with biaxial residual stresses by in-situ XRD stress analysis combined with tensile test, Surface \& Coatings Technology, Vol. 192 (2005), pp. 139-144.

(9) Ma D., Xu K., He J. and Lu J., Evaluation of the mechanical properties of thin metal films, Surface and Coatings Technology, Vols. 116-119 (1999), pp. 128-132.

(10) Gouldstone A., Koh H.-J., Zeng K.-Y., Giannakopoulos A. E. and Suresh S., Discrete and continuous deformation during nanoindentation of thin films, Acta Materialia, Vol. 48 (2000), pp. 2277-2295.

(11) Schadler L. and Noyan I.C., Experimental determination of the strain transfer across a flexible intermediate layer in thin-film structures, Journal of Materials Science Letters, Vol. 11 (1992), pp. 1067-1069.

(12) Schadler L. and Noyan I.C., Quantitative measurement of the stress transfer function in nickel/polyimide thin film/copper thin film structures, Applied Physics Letters, Vol. 66 (1) (1995), pp. 22-24.

(13) Kraft O., Schwaiger R. and Wellner P., Fatigue in thin films: lifetime and damage formation, Materials Science and Engineering, A, Vols. 319-321 (2001), pp. 919-923.

(14) Zhang G.P., Volkert C.A., Schwaiger R., Wellner P., Arzt E. and Kraft O., Length-scale-controlled fatigue mechanisms in thin copper films, Acta Materialia, Vol. 54 (2006), pp. 3127-3139.

(15) Akiniwa Y., Suzuki T., Aoki K., Kawai M. and Tanaka K., X-ray evaluation of deformation damage in electrodeposited copper foil under tensile and fatigue loading, Journal of the Society of Materials Science, Japan, Vol. 55 (2006), pp. 627-633.

(16) Akiniwa Y., Suzuki T. and Kimura H., X-ray evaluation of deformation behaviour of copper thin films under uniaxial loading, Transactions of the Japan Society of Mechanical Engineers, A, Vol. 74 (2008), pp. 356-362.

(17) Warren B.E. and Averbach B.L., The effect of cold-work distribution on X-ray patterns, Journal of Applied Physics, Vol. 21 (1950), pp.595-595.

(18) Wei Q, Kecskes L, Jiao T, Hartwig K.T., Ramesh K.T., Ma E., Acta Materialia, Vol. 52 (2004), pp.1859- 1869 .

(19) Hoeppel H.W., Zhou Z.M., Mughrabi H. and Valiev R.Z., Microstructural study of the parameters governing coarsening and cyclic softening in fatigued ultrafine-grained copper, Philosophical Magazine A, Vol. 82 (2002), pp. 1781-1794.

(20) Kimura H., Kojima Y., Akiniwa Y., Tanaka K. and Ishida T., Fatigue damage mechanism of nanocrystals in ECAP-processed copper investigated by EBSD and AFM hybrid methods, Key Engineering Materials, Vols. 340-341 (2007), pp. 943-948. 